\title{
Effects of dietary nitrogen levels and carbohydrate sources on apparent ruminal synthesis of some $B$ vitamins in dairy cows
}

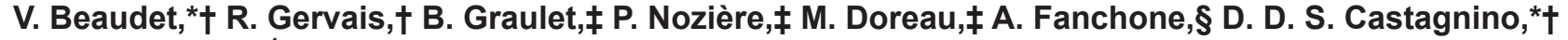 \\ and C. L. Girard*1 \\ *Agriculture and Agri-Food Canada, Dairy and Swine Research and Development Centre, Sherbrooke, Québec, J1M 0C8, Canada \\ †Département des sciences animales, Université Laval, Québec, Québec, G1V 0A6, Canada \\ †INRA-VetagroSup, UMR1213 Herbivores, F-63122 Saint-Genès-Champanelle, France \\ §INRA, UR143 Unité de Recherches Zootechniques, F-97170 Petit-Bourg, Guadeloupe, France
}

\begin{abstract}
Effects of nitrogen level and carbohydrate source on apparent ruminal synthesis (ARS) of thiamin, riboflavin, niacin, vitamin $B_{6}$, folates, and vitamin $B_{12}$ were evaluated using 4 lactating Holstein cows distributed in a $4 \times 4$ Latin square design with treatments following a $2 \times 2$ factorial arrangement. Cows were fitted with cannulas in the rumen and proximal duodenum. The treatments were $2 \mathrm{~N}$ levels and 2 carbohydrate sources. The diet with the high $\mathrm{N}$ level provided $14 \%$ crude protein, calculated to meet $110 \%$ of the protein requirements and an adequate supply in rumen-degradable protein, whereas the diet with the low $\mathrm{N}$ level contained $11 \%$ crude protein, calculated to meet $80 \%$ of the protein requirements with a shortage in rumen-degradable protein. Carbohydrate source treatments differed by their nature (i.e., high in starch from barley, corn, and wheat, or high in fiber from soybean hulls and dehydrated beet pulp). All 4 diets were isoenergetic, based on corn silage, and had the same forage-to-concentrate ratio (60:40, dry matter basis). Duodenal flow was determined using $\mathrm{YbCl}_{3}$ as a marker. Each B-vitamin ARS was calculated as duodenal flow minus daily intake. The intake of several B vitamins varied among treatments, but because the animals consumed a similar amount of feed every day (average of $20 \mathrm{~kg}$ of dry matter/d) the difference was mostly due to vitamin content of each ingredient and their relative proportion in the diets. Decreasing $\mathrm{N}$ concentration in the diet reduced vitamin $\mathrm{B}_{6}$ duodenal flow and increased its apparent ruminal degradation. It also decreased duodenal flow and ARS of folates. The high-starch diets increased duodenal flow and ruminal balance of riboflavin, vitamin $\mathrm{B}_{6}$, and folates, whereas the high-fiber diets increased vitamin $\mathrm{B}_{12}$ ARS and duodenal flow. These effects on apparent synthesis are possibly due to changes in ruminal fermentation.
\end{abstract}

Received October 14, 2015.

Accepted December 14, 2015

${ }^{1}$ Corresponding author: Christiane.Girard@agr.gc.ca
Key words: dairy cow, B-vitamin ruminal synthesis, nitrogen, carbohydrate source

\section{INTRODUCTION}

In the early 20th century, several studies demonstrated synthesis of B vitamins in the rumen of dairy cows. From these data, it was concluded that ruminants with a balanced diet and a functional rumen could meet their requirements in B vitamins (Bechdel and Honeywell, 1927; Bechdel et al., 1928; Kon and Porter, 1954), and therefore deficiencies in these nutrients should not be a concern for dairy nutritionists. Even though they are required in small amounts, B vitamins play an essential role as they act as cofactors or coenzymes in the metabolism of carbohydrates, lipids, proteins, and nucleic acids (Combs, 2012). Several researchers have shown that B-vitamin supplements can improve milk yield, composition, and metabolic efficiency in highproducing dairy cows (Jaster and Ward, 1990; Girard and Matte, 1998; Shaver and Bal, 2000; Graulet et al., 2007). However, the response to these dietary supplements is highly variable and one of the major reasons is because the amounts of vitamins provided by the basal diet and the synthesis in the rumen are unknown. Dietary characteristics, such as carbohydrate source and protein supply, affect fermentation and microorganisms in the rumen (Johnson and Johnson, 1995; Hristov et al., 2001; Belanche et al., 2012). For example, easily fermentable carbohydrates, such as starch, are more efficient than other carbohydrates, such as cellulose, to promote microbial growth (Bach et al., 2005), whereas reduction in nitrogen supply can lead to a lower rumen microbial diversity and abundance (Belanche et al., 2012). To our knowledge, information on the effect of $\mathrm{N}$ level and carbohydrate source on B-vitamin apparent ruminal synthesis (ARS) is very limited. Therefore, our study was undertaken to identify the effects of these 2 parameters and their interaction on intake, duodenal flow and ARS of some B vitamins in lactating dairy cows. 


\section{MATERIALS AND METHODS}

The experimental procedures were conducted in accordance with national legislation issued by the French government (Ministère de l'Alimentation, de l'Agriculture et de la Pêche, 2009) and international recommendation (Canadian Council on Animal Care, 1993) on the care and use of laboratory animals.

\section{Animals and Treatments}

The experimental procedures were described in details by Fanchone et al. (2013). Briefly, we used 4 Holstein cows fitted with cannulas in the rumen and the proximal duodenum and weighing on average 662 $\pm 62 \mathrm{~kg}$ at $71 \pm 10 \mathrm{~d}$ of lactation (mean $\pm \mathrm{SD}$ ) at the beginning of the experiment. The experimental design was a $4 \times 4$ Latin square design with each experimental period lasting $28 \mathrm{~d}$, with $22 \mathrm{~d}$ of adaptation to the diet and $6 \mathrm{~d}$ for sampling. Treatments were 2 levels of $\mathrm{N}$ and 2 carbohydrate sources in a factorial arrangement. The high level of $\mathrm{N}$ met $110 \%$ of protein requirements of cows whereas the low level covered $80 \%$ of these requirements, expressed in the French system of protein digestible in the intestine (INRA, 2007) with a shortage in rumen-degradable protein (NRC, 2001). The difference between the 2 carbohydrate sources was based on the nature of concentrates (i.e., rich in starch or rich in fiber). Diets were corn silage-based, had the same forage-to-concentrate ratio (60:40, DM basis), were isoenergetic, and formulated to meet net energy theoretical requirements (INRA, 2007; Table 1). The amount of feed offered daily was restricted at $95 \%$ of voluntary intake measured at the beginning of the study and adjusted at the beginning of each experimental period to net energy theoretical requirements (Fanchone et al., 2013). Each ingredient was weighed individually before distribution as a TMR. Intake was the difference between the amounts of feed offered and refused daily for each cow from d 22 to 28 . Water was provided ad libitum.

\section{Sample and Data Collection}

Measurements and sampling procedures to characterize ruminal fermentation (VFA, $\mathrm{pH}, \mathrm{NH}_{3}-\mathrm{N}$ ), NAN duodenal flow, rumen digestibility, and $\mathrm{N}$ balance have been described by Fanchone et al. (2013).

\section{Laboratory Analyses}

B-vitamin concentrations were determined in feed and duodenal digesta samples. Concentrations of thia- min, riboflavin, niacin, and vitamin $\mathrm{B}_{6}$ were determined by HPLC (Varian Prostar, Lake Forest, CA) with a solvent delivery system (model 210), an autosampler (model 410), and a fluorescence detection system (model 363). Folates were analyzed with a microbiological microtiter plate test (VitaFast Folic Acid, R-Biopharm Inc., Marshall, MI) and vitamin $\mathrm{B}_{12}$ was analyzed by radio-assay (SimulTRAC-S Vitamin $\mathrm{B}_{12}\left[\mathrm{Co}^{57}\right] /$ Folate $\left[\mathrm{I}^{125}\right]$, MP Biomedicals, Solon, OH). Cobalt concentration in feed was determined by atomic absorption spectrometer (PerkinElmer, Waltham, MA).

Thiamin (B1). Thiamin concentrations were analyzed in duplicate by HPLC according to a method adapted from Bötticher and Bötticher (1986). Standard curves were prepared as followed: a standard stock solution was prepared by dissolving $33.7 \mathrm{mg}$ of thiamin hydrochloride (Sigma-Aldrich, Oakville, ON, Canada) in a final volume of $100 \mathrm{~mL}$ of $0.01 \mathrm{M} \mathrm{H}_{2} \mathrm{SO}_{4}$ solution (Fisher Scientific, Ottawa, ON, Canada). Then, $400 \mu \mathrm{L}$ of the solution was diluted in $1,600 \mu \mathrm{L}$ of ultrapure water to obtain an initial concentration of $200 \mu M$ thiamin, which was used to obtain a 7-level standard curve $(0.3-7.5 \mu M)$. For the feed and digesta, $0.1 \mathrm{~g}$ of sample and $5 \mathrm{~mL}$ of $\mathrm{H}_{2} \mathrm{SO}_{4}$ were mixed in a $15-\mathrm{mL}$ polypropylene conical tube and autoclaved $\left(100^{\circ} \mathrm{C}, 15\right.$ min). After cooling in an ice bath, $\mathrm{pH}$ was adjusted to 4.5 with $4.0 \mathrm{M} \mathrm{C}_{2} \mathrm{H}_{3} \mathrm{NaO}_{2}$ buffer (Sigma-Aldrich) and $500 \mu \mathrm{L}$ of $1 \%$ reduced glutathione (Sigma-Aldrich) was added to each tube. Next, according to the methods adapted from Hyun and Tamura (2005) and Jakobsen (2008), $1 \mathrm{~mL}$ of an aqueous trienzyme mix was added, containing papain (60 U, Sigma-Aldrich), $\alpha$-amylase (10,167 U, Sigma-Aldrich), and acid phosphatase (14 U, Sigma-Aldrich). The samples were incubated (60 min) in an ultrasonic bath (Ultrasonic Cleaners, 40 $\mathrm{kHz}$, Cole-Parmer, Montréal, QC, Canada) and then autoclaved to inactivate the enzymes $\left(100^{\circ} \mathrm{C}, 5 \mathrm{~min}\right)$. After cooling in an ice bath, the volume was completed to $7 \mathrm{~mL}$ with ultrapure water and centrifuged (900 $\left.\times g, 10 \mathrm{~min}, 4^{\circ} \mathrm{C}\right)$. Immediately following centrifugation, the supernatant $(1 \mathrm{~mL})$ was mixed with $225 \mu \mathrm{L}$ of oxidative solution $[175 \mu \mathrm{L}$ of $50 \% \mathrm{NaOH}$ and 50 $\mu \mathrm{L}$ of $5 \% \mathrm{~K}_{3} \mathrm{FeCN}_{6}$ (Avantor Performance Materials, Center Valley, PA) per sample]. After incubation (5 min), approximately $0.25 \mathrm{~g}$ of $\mathrm{NaCl}$ was added to each tube. Following mixing, $2 \mathrm{~mL}$ of 2-butanol was added, the samples were shaken for $1 \mathrm{~min}$ and then $10 \mu \mathrm{L}$ was injected into the HPLC. The analysis was carried out on a Polaris- $\mathrm{NH}_{2}$ column $(250 \mathrm{~mm} \times 4.6 \mathrm{~mm}, 5$ $\mu \mathrm{m}$; Agilent, Mississauga, ON, Canada) preceded by a guard column (MetaGuard Polaris- $\mathrm{NH}_{2}, 4.6 \mathrm{~mm}, 3 \mu \mathrm{m}$, Agilent). The mobile phase was composed of $250 \mathrm{~mL}$ of $0.04 \mathrm{M} \mathrm{KH}_{2} \mathrm{PO}_{4}$ buffer and $750 \mathrm{~mL}$ of acetonitrile at a flow rate of $1.5 \mathrm{~mL} / \mathrm{min}$, with the fluorimetric detection 
system adjusted at 425 and $370 \mathrm{~nm}$ for emission and excitation, respectively. Mean intra-assay coefficients of variation were 2.4 and $2.8 \%$ for feed and digesta, respectively, and recovery rate was $89 \%$.

Riboflavin $\left(\boldsymbol{B}_{2}\right)$. Riboflavin concentrations were determined in duplicate according to a method adapted from Giguère et al. (2002). Initial solutions of riboflavin $(2,656 \mu M)$ and flavin-adenine dinucleotide (FAD; $2,411 \mu M$; Sigma-Aldrich) were used to obtain standard curves with 6 concentration levels (5.31 to 79.70 and 5.30 to 79.57 , respectively). All forms of the vitamin were transformed into riboflavin for analysis and the FAD curve was made to confirm the efficiency of the reaction. Feed and digesta samples $(0.2 \mathrm{~g})$ were acidified in $10 \mathrm{~mL}$ of $0.1 \mathrm{M} \mathrm{HCl}$ (Fisher Scientific) in 50-mL polypropylene conical tubes and autoclaved for $30 \mathrm{~min}$ at $100^{\circ} \mathrm{C}$. After cooling in an ice bath, $\mathrm{pH}$ was adjusted to 4.5 with $4.0 \quad \mathrm{M} \mathrm{C}_{2} \mathrm{H}_{3} \mathrm{NaO}_{2}$ buffer (Sigma-Aldrich) and $500 \mu \mathrm{L}$ of $1 \%$ reduced glutathione (Sigma-Aldrich) were added in each tube. Next, $1 \mathrm{~mL}$ of a trienzyme solution as used for thiamin analysis was added. The samples were incubated ( $1 \mathrm{~h} 25 \mathrm{~min}$ ) in an ultrasonic bath (Ultrasonic Cleaners, $40 \mathrm{kHz}$, Cole-Parmer) and then autoclaved $\left(100^{\circ} \mathrm{C}, 5 \mathrm{~min}\right)$. After cooling in an ice bath, the volume was made up to $15 \mathrm{~mL}$ with ultrapure water and centrifuged $\left(900 \times g, 10 \mathrm{~min}, 4^{\circ} \mathrm{C}\right)$.

Table 1. Ingredient, chemical composition, nutritive value, and vitamin concentrations of the diets fed to dairy cows receiving high-starch or high-fiber concentrate with a low or high $\mathrm{N}_{\text {level }}{ }^{1}$

\begin{tabular}{|c|c|c|c|c|}
\hline \multirow[b]{2}{*}{ Item } & \multicolumn{2}{|c|}{ Low $\mathrm{N}$} & \multicolumn{2}{|c|}{ High N } \\
\hline & Starch & Fiber & Starch & Fiber \\
\hline \multicolumn{5}{|l|}{ Ingredient. ${ }^{2} \%$ of DM } \\
\hline Corn silage & 40.5 & 40.5 & 40.5 & 40.5 \\
\hline Hay & 10.0 & 10.0 & 10.0 & 10.0 \\
\hline Dehydrated alfalfa & 9.0 & 9.0 & 9.0 & 9.0 \\
\hline Molasses chopped wheat straw & 6.3 & 0 & 5.2 & 0 \\
\hline Cereal-based concentrate ${ }^{3}$ & 30.6 & 0 & 24.3 & 0 \\
\hline Soybean hulls & 0 & 31.0 & 0 & 22.4 \\
\hline Dehydrated beet pulp & 0 & 9.0 & 0 & 9.0 \\
\hline Soybean meal & 3.6 & 0 & 10.8 & 8.6 \\
\hline Urea & 0 & 0.5 & 0.2 & 0.5 \\
\hline \multicolumn{5}{|l|}{ Chemical composition, $\%$ of DM } \\
\hline $\mathrm{OM}$ & 94.3 & 93.3 & 93.8 & 93.0 \\
\hline NDF & 36.2 & 50.7 & 36.1 & 47.1 \\
\hline $\mathrm{ADF}$ & 18.8 & 30.7 & 18.4 & 27.4 \\
\hline $\mathrm{CP}$ & 11.0 & 11.1 & 14.2 & 14.4 \\
\hline Starch & 32.4 & 15.1 & 29.0 & 15.3 \\
\hline \multicolumn{5}{|l|}{ Nutritive value } \\
\hline $\mathrm{NE}_{\mathrm{L}}, \mathrm{kJ} / \mathrm{kg}$ of $\mathrm{DM}$ & 6,683 & 6,535 & $6,753.0$ & 6,650 \\
\hline $\mathrm{PDIE}^{4}, \mathrm{~g} / \mathrm{kg}$ of DM & 87 & 87 & 99 & 100 \\
\hline $\mathrm{PDIN}^{5} \mathrm{~g} / \mathrm{kg}$ of DM & 71 & 70 & 96 & 97 \\
\hline $\mathrm{RDP}^{6} \mathrm{~g} / \mathrm{kg}$ of DM & 74 & 76 & 98 & 97 \\
\hline $\mathrm{RUP}^{6} \mathrm{~g} / \mathrm{kg}$ of DM & 36 & 39 & 46 & 50 \\
\hline $\mathrm{MP},{ }^{6} \mathrm{~g} / \mathrm{kg}$ of $\mathrm{DM}$ & 88 & 84 & 97 & 96 \\
\hline Total cobalt, $\mathrm{mg} / \mathrm{kg}$ of $\mathrm{DM}$ & 0.695 & 1.050 & 0.948 & 1.135 \\
\hline \multicolumn{5}{|c|}{ Vitamin concentration, $\mathrm{mg} / \mathrm{kg}$ of $\mathrm{DM}$} \\
\hline Thiamin & 2.63 & 1.59 & 2.45 & 1.61 \\
\hline Riboflavin & 58.90 & 51.30 & 58.38 & 52.23 \\
\hline Niacin & 106.12 & 107.71 & 106.56 & 107.72 \\
\hline Vitamin $\mathrm{B}_{6}$ & 10.24 & 7.87 & 9.95 & 8.06 \\
\hline Folates & 0.48 & 0.67 & 0.61 & 0.76 \\
\hline Vitamin $\mathrm{B}_{12}$ & 0.004 & 0.004 & 0.004 & 0.004 \\
\hline
\end{tabular}

${ }^{1}$ Ingredients, chemical compositions, and nutritive values from Fanchone et al. (2013).

${ }^{2}$ Each cow received $200 \mathrm{~g} / \mathrm{d}$ of a vitamin and trace element premix provided in the daily diet: $2.5 \% \mathrm{P}, 20 \%$ $\mathrm{Ca}, 4.5 \% \mathrm{Mg}, 3.5 \% \mathrm{Na}, 400,000 \mathrm{IU} / \mathrm{kg}$ of vitamin $\mathrm{A}, 120,000 \mathrm{IU} / \mathrm{kg}$ of vitamin $\mathrm{D}_{3}, 1,600 \mathrm{mg} / \mathrm{kg}$ of vitamin E, $1,300 \mathrm{mg} / \mathrm{kg}$ of copper sulfate, $5,000 \mathrm{mg} / \mathrm{kg}$ of zinc oxide, $3,500 \mathrm{mg} / \mathrm{kg}$ of manganese oxide, $90 \mathrm{mg} / \mathrm{kg}$ of calcium iodate, $36 \mathrm{mg} / \mathrm{kg}$ of cobalt carbonate, and $20 \mathrm{mg} / \mathrm{kg}$ of sodium selenite; Galaphos Midi Duo, CCPA, Aurillac, France.

${ }^{3}$ Cereal-based concentrate: $39 \%$ barley, $46 \%$ wheat, and $15 \%$ corn, on a DM basis.

${ }^{4} \mathrm{PDIE}=$ protein digested in the small intestine supplied by rumen-undegraded dietary protein and by microbial protein from rumen-fermented OM (INRA, 2007).

${ }^{5} \mathrm{PDIN}=$ protein digested in the small intestine supplied by rumen-undegraded dietary protein and by microbial protein from rumen degraded N (INRA, 2007).

${ }^{6}$ Calculated from NRC feed tables (NRC, 2001) using the actual DMI level (on average, $3.04 \%$ BW). 
The supernatant $(500 \mu \mathrm{L})$ was combined with $200 \mu \mathrm{L}$ of $15 \% \mathrm{HClO}_{4}$ solution, and samples were then boiled for $10 \mathrm{~min}$. Following centrifugation $(900 \times g, 10 \mathrm{~min}$, $\left.4^{\circ} \mathrm{C}\right)$, the supernatant $(400 \mu \mathrm{L})$ was mixed with $200 \mu \mathrm{L}$ of $4.0 \mathrm{M} \mathrm{C}_{2} \mathrm{H}_{3} \mathrm{NaO}_{2}$ and $25 \mu \mathrm{L}$ of $2 \%$ acid phosphatase solution $\left[20 \mathrm{mg}\right.$ of phosphatase $/ \mathrm{mL}$ of $\mathrm{C}_{2} \mathrm{H}_{7} \mathrm{NO}_{2}$ buffer $(50 \mathrm{~m} M, \mathrm{pH} 4.0)]$. Samples were incubated $\left(37^{\circ} \mathrm{C}\right.$, $18 \mathrm{~h}$ ) in a water bath to convert FAD into riboflavin. Following centrifugation $\left(10,000 \times g, 10 \mathrm{~min}, 4^{\circ} \mathrm{C}\right)$, the supernatants were injected into the HPLC. Analysis was carried out with a Pursuit $5 \mu \mathrm{m} \mathrm{C18}$ column (150 $\times 4.6 \mathrm{~mm}$; Varian, Mississauga, ON, Canada) preceded by a guard column (MetaGuard Pursuit $5 \mu \mathrm{m} \mathrm{C18,} 4.6$ $\mathrm{mm}$; Agilent). The mobile phase was composed of 80 $\mathrm{mL}$ of $\mathrm{C}_{2} \mathrm{H}_{7} \mathrm{NO}_{2}$ buffer ( $\mathrm{pH} 4.0$ ), $800 \mathrm{~mL}$ of ultrapure water, and $200 \mathrm{~mL}$ of acetonitrile, at a flow rate of 1.0 $\mathrm{mL} / \mathrm{min}$ and the fluorimetric detection system adjusted at 520 and $450 \mathrm{~nm}$ for emission and excitation, respectively. The mean intra-assay coefficients of variation were 4.3 and $2.3 \%$ for feed and digesta, respectively, and recovery rate was $102 \%$.

Niacin (B3). Concentrations of the 2 forms of niacin, nicotinic acid (NA) and nicotinamide (NAM) were analyzed in duplicate by HPLC with fluorometric detection based on adaptation of methods of Mawatari et al. (1991), Lahély et al. (1999), and Ndaw et al. (2002). Standard solutions were prepared by dissolving $0.01 \mathrm{~g}$ of NA and NAM (Sigma-Aldrich) in $100 \mathrm{~mL}$ of ultrapure water. Six concentrations of NA (5.04 to 99.99 $\mu M$ ) and NAM (5.16 to $100.00 \mu M$ ) were used for the standard curves. Then, $0.2 \mathrm{~g}$ of sample, feed, or digesta was acidified in $10 \mathrm{~mL}$ of $0.1 \mathrm{M} \mathrm{HCl}$ (Fisher Scientific) in a 50-mL polypropylene conical tube and autoclaved $30 \mathrm{~min}$ at $100^{\circ} \mathrm{C}$. After cooling in an ice bath, $\mathrm{pH}$ was adjusted to 4.5 with $4.0 \mathrm{M} \mathrm{C}_{2} \mathrm{H}_{3} \mathrm{NaO}_{2}$ buffer (SigmaAldrich) and $500 \mu \mathrm{L}$ of $1 \%$ reduced glutathione (SigmaAldrich) were added in each sample. Next, the same trienzyme mix as for thiamin analyses was applied. The samples were incubated ( $1 \mathrm{~h} 25 \mathrm{~min})$ in an ultrasonic bath (Ultrasonic Cleaners, $40 \mathrm{kHz}$, Cole-Parmer) and then autoclaved $\left(100^{\circ} \mathrm{C}, 5 \mathrm{~min}\right)$. After cooling in an ice bath, the volume was adjusted to $15 \mathrm{~mL}$ with ultrapure water and centrifuged $\left(900 \times g, 10 \mathrm{~min}, 4^{\circ} \mathrm{C}\right)$. The supernatants $(2 \mathrm{~mL})$ were collected and $20 \mu \mathrm{L}$ were injected into the HPLC. Samples were run through a Pursuit $5 \mu \mathrm{m}$ C18 column $(150 \times 4.6 \mathrm{~mm}$; Agilent $)$ preceded by a guard column (MetaGuard Pursuit $5 \mu \mathrm{m}$ C18, $4.6 \mathrm{~mm}$; Agilent). The postcolumn photochemical reaction was carried out in a polytetra-fluoroethylene tube $(10 \mathrm{~m} \times 0.5 \mathrm{~mm})$, which was wound around a black light (Black-Ray, model XX-20BLB, 300-400 nm with a filter excluding the 254-nm line, $115 \mathrm{~V}, 60 \mathrm{~Hz}, 60 \mathrm{~A}$; UVP, Upland, CA). The mobile phase consisted of 0.07 $M \mathrm{KH}_{2} \mathrm{PO}_{4}$ buffer containing $0.075 M \mathrm{H}_{2} \mathrm{O}_{2}$ and $5.1 \mu M$ copper II sulfate (Sigma-Aldrich). The flow rate was adjusted to $1.5 \mathrm{~mL} / \mathrm{min}$, and the fluorimetric detector operated at an excitation wavelength of $322 \mathrm{~nm}$ and an emission wavelength of $380 \mathrm{~nm}$. Total niacin daily intake, duodenal flow, and ARS were the summation of NA and NAM for these variables. The mean intra-assay coefficients of variation were 10.56 and $4.4 \%$ in feed and digesta, respectively, and recovery rate was $96 \%$.

Vitamin $\boldsymbol{B}_{6}$. The 3 forms of vitamin $\mathrm{B}_{6}$, pyridoxamine (PAM), pyridoxal (PAL), and pyridoxine (PYR), were determined in duplicate by adaptation of methods described by Srivastava and Beutler (1973) and Matte et al. (1997). Four stock solutions made in ultrapure water $(500 \mu \mathrm{g} / \mathrm{mL}$; Sigma-Aldrich $)$ of PAM, PAL, PYR, and pyridoxal-5'-phosphate (P5P) were diluted (one-tenth for PAM, PAL, and P5P; one-thirtieth for PYR) to obtain standard solutions (respectively, 207, 246, 202, and $81 \mu M$ ). Feed and digesta samples were analyzed for PAM, PAL, and PYR simultaneously, whereas P5P was converted to PAL before analysis. A separate standard curve was made for P5P to validate the efficiency of the transformation into PAL. In a 50$\mathrm{mL}$ polypropylene conical tube, $10 \mathrm{~mL}$ of $0.1 \mathrm{M} \mathrm{H}_{2} \mathrm{SO}_{4}$ solution was added to $0.2 \mathrm{~g}$ of sample as solid material and autoclaved $\left(100^{\circ} \mathrm{C}, 15 \mathrm{~min}\right)$. After cooling in an ice bath, $\mathrm{pH}$ was adjusted to 4.5 with $4.0 \mathrm{M} \mathrm{C}_{2} \mathrm{H}_{3} \mathrm{NaO}_{2}$ buffer (Sigma-Aldrich) and $500 \mu \mathrm{L}$ of $1 \%$ reduced glutathione (Sigma-Aldrich) was added to each tube. Next, adapted from the method of Hyun and Tamura (2005), $1 \mathrm{~mL}$ of an aqueous solution of papain $(60$ U, Sigma-Aldrich) and $\alpha$-amylase $(10,167 \mathrm{U}$, SigmaAldrich) was added. The samples were incubated $(1 \mathrm{~h}$ $25 \mathrm{~min}$ ) in an ultrasonic bath (Ultrasonic Cleaners, 40 $\mathrm{kHz}$, Cole-Parmer) and then autoclaved $\left(100^{\circ} \mathrm{C}, 5 \mathrm{~min}\right)$. After cooling in an ice bath, the volume was made up to $20 \mathrm{~mL}$ with ultrapure water and centrifuged $(900 \times$ $\left.g, 10 \mathrm{~min}, 4^{\circ} \mathrm{C}\right)$. Immediately following centrifugation, the supernatant $(1 \mathrm{~mL})$ was incubated $\left(37^{\circ} \mathrm{C}, 18 \mathrm{~h}\right)$ with $25 \mu \mathrm{L}$ of $2 \%$ phosphatase acid solution $[20 \mathrm{mg}$ of phosphatase per $\mathrm{mL}$ of $\mathrm{C}_{2} \mathrm{H}_{7} \mathrm{NO}_{2}$ buffer $(50 \mathrm{mM}$, $\mathrm{pH} 4.0)]$ to convert P5P into PAL. The samples were then centrifuged $\left(10,000 \times g, 10 \mathrm{~min}, 4^{\circ} \mathrm{C}\right)$ before being injected into the HPLC, using the same model of column as for niacin analyses. The mobile phase for vitamin $\mathrm{B}_{6}$ consisted of $0.09 \mathrm{M} \mathrm{H}_{2} \mathrm{SO}_{4}$ at a flow rate of $1.5 \mathrm{~mL} / \mathrm{min}$. Emission and excitation wavelengths of the fluorimetric detection system were respectively 290 and $395 \mathrm{~nm}$. Total vitamin $\mathrm{B}_{6}$ daily intake, duodenal flow, and ARS were the summation of PAM, PAL, and PYR for these variables. Although concentrations of some forms of the vitamin were lower than the first standard, the mean intra-assay coefficient of variation were 4.5 and $3.4 \%$ in feed and digesta, respectively, and recovery rate was $95 \%$. 
Folates $\left(\boldsymbol{B}_{g}\right)$. The method of extraction was adapted from AOAC International $(2005 ; 960.46)$ using the following extraction solution: $14.2 \mathrm{~g}$ of $\mathrm{Na}_{2} \mathrm{HPO}_{4}$ (Fisher Scientific) and $10 \mathrm{~g}$ of $\mathrm{C}_{6} \mathrm{H}_{8} \mathrm{O}_{7}$ (Sigma-Aldrich) in $1 \mathrm{~L}$ of ultrapure water $(\mathrm{pH} 7.3)$. In a $50-\mathrm{mL}$ polypropylene conical tube, $5 \mathrm{~mL}$ of this phosphate buffer was mixed with $0.1 \mathrm{~g}$ of solid material. According to the method adapted from Hyun and Tamura (2005), $100 \mu \mathrm{L}$ of a papain solution made in ultrapure water (60 U, SigmaAldrich) was added and all samples were incubated $\left(37^{\circ} \mathrm{C}, 1 \mathrm{~h} 30 \mathrm{~min}\right)$. The samples were autoclaved to inactivate the enzyme $\left(100^{\circ} \mathrm{C}, 5 \mathrm{~min}\right)$ and cooled in an ice bath, and then $100 \mu \mathrm{L}$ of $\alpha$-amylase $(10167 \mathrm{U}$, Sigma-Aldrich) and $200 \mu \mathrm{L}$ of conjugase solutions made in ultrapure water $(5 \mathrm{mg} / \mathrm{mL}$, Pel-Freez Biologicals, Rogers, AR) were added. All samples were incubated $\left(37^{\circ} \mathrm{C}, 3 \mathrm{~h}\right)$ before autoclaving $\left(100^{\circ} \mathrm{C}, 5 \mathrm{~min}\right)$. Following cooling at room temperature, the volume was completed to $40 \mathrm{~mL}$ with ultrapure water. Next, the tubes were centrifuged $\left(5,000 \times g, 10 \mathrm{~min}, 4^{\circ} \mathrm{C}\right)$ and the supernatants were used to determine folate concentration using the commercial microbiological microtiter plate test (VitaFast Folic Acid, R-Biopharm Inc.). This procedure used Lactobacillus rhamnosus, which responds to the widest variety of folate biological active forms (Bird and McGlohon, 1972; Tamura et al., 1972). Samples were analyzed in triplicate on the microtiter plate and the mean intra-assay coefficient of variation were 4.4 and $3.5 \%$ for feed and digesta, respectively, and recovery rate was $100 \%$.

Vitamin $\boldsymbol{B}_{12}$. The method of extraction was adapted from AOAC International $(2005 ; 952.20)$ using the following extractive solution: $13 \mathrm{~g}$ of $\mathrm{Na}_{2} \mathrm{HPO}_{4}$ (Fisher Scientific), $12 \mathrm{~g}$ of $\mathrm{C}_{6} \mathrm{H}_{8} \mathrm{O}_{7}$ (Sigma-Aldrich), and $10 \mathrm{~g}$ of $\mathrm{Na}_{2} \mathrm{~S}_{2} \mathrm{O}_{5}$ (Fisher Scientific) in $1 \mathrm{~L}$ of ultrapure water. A sample of $0.1 \mathrm{~g}$ of solid material was hydrolyzed with $20 \mathrm{~mL}$ of extractive solution and $150 \mu \mathrm{L}$ of $1.0 \mathrm{M}$ $\mathrm{NaCN}$ (Sigma-Aldrich) were added before autoclaving $\left(100^{\circ} \mathrm{C}, 10 \mathrm{~min}\right)$. Subsequently, the tubes were cooled at room temperature and the $\mathrm{pH}$ was adjusted with $3.3 \mathrm{M} \mathrm{NaOH}$ at $\mathrm{pH} 6.2$ to 6.5. The final volume was $30 \mathrm{~mL}$ after addition of ultrapure water and samples were centrifuged $\left(3,000 \times g, 10 \mathrm{~min}, 4^{\circ} \mathrm{C}\right)$. A volume of $200 \mu \mathrm{L}$ of the supernatant was used to determine the concentration of the biologically active form of vitamin $\mathrm{B}_{12}$ using a commercial kit (SimulTRAC-S Vitamin $\mathrm{B}_{12}$ $\left[\mathrm{Co}^{57}\right] /$ Folate $\left[\mathrm{I}^{125}\right]$, MP Biomedicals). All samples were analyzed in duplicate and the mean intra-assay coefficient of variation in digesta was $3.4 \%$, whereas that of feed is not presented because many samples were below detection limit. Recovery rate was $99 \%$.

Cobalt. Cobalt concentration in the dietary ingredients was determined by atomic absorption spectrometer with flame stoichiometric air-acetylene at 240.7 $\mathrm{nm}$ based on an adaptation of the method of Bellanger (1988). Aliquots of $1.0 \mathrm{~g}$ of feed were dry ashed for $18 \mathrm{~h}$ at $500^{\circ} \mathrm{C}$ with a hold at $350^{\circ} \mathrm{C}$ for $1 \mathrm{~h}$. Then, dry ashed samples were dissolved in $6.0 \mathrm{M} \mathrm{HCl}$ and homogenized in an ultrasonic bath (Ultrasonic Cleaners, $40 \mathrm{kHz}$, Cole-Parmer) for $30 \mathrm{~min}$. If needed, further dilutions were made with $1.0 \mathrm{M} \mathrm{HCl}$. A coefficient of variation below $10 \%$ was accepted.

\section{Calculations and Statistical Analyses}

B-vitamin concentrations in the diets were calculated based on B-vitamin concentrations in each ingredient multiplied by the proportion of this ingredient in the experimental diets on a DM basis. Daily intake of each vitamin was calculated as the concentration of each vitamin in the diet multiplied by the amount ingested, on a DM basis. Calculation of DM duodenal flows was described by Fanchone et al. (2013). Duodenal flow of vitamins was calculated as B-vitamin concentrations in the duodenal sample, on a DM basis, multiplied by the daily DM flowing through the duodenum. The ARS was calculated as the duodenal flow minus daily intake.

Daily intake, duodenal flow, and ARS for each vitamin were analyzed according to a $4 \times 4$ Latin square design using the MIXED procedure of SAS (2008) according to the following model:

$$
\mathrm{Y}_{i j k l}=\mu+\beta_{i}+\mathrm{K}_{j}+\mathrm{N}_{k}+\mathrm{C}_{l}+\mathrm{N}_{k} \times \mathrm{C}_{l}+\varepsilon_{i j k l},
$$

where $\mathrm{Y}_{i j k l}$ is the studied variable, $\mu$ the overall mean, $\beta_{i}$ the cow effect, $\mathrm{K}_{j}$ the period effect, $\mathrm{N}_{k}$ the $\mathrm{N}$ level effect, $\mathrm{C}_{l}$ the carbohydrate source effect, $\mathrm{N}_{k} \times \mathrm{C}_{l}$ their interaction effect, and $\varepsilon_{i j k l}$ the residual error. The statistical model included $\mathrm{N}$ level, carbohydrate source, and their interaction as fixed effects and cow as a random effect. A factorial design was used to test the effect of the 2 levels of $\mathrm{N}$, the 2 carbohydrate sources and their interaction. Differences were declared significant at $P<$ 0.05 and as a tendency at $0.05 \leq P \leq 0.10$. When the interaction was or tended to be significant, a slice test was made to interpret the interaction. Pearson correlation coefficients were determined between B-vitamin ARS and dietary parameters.

\section{RESULTS AND DISCUSSION}

B-vitamin concentrations in diets and dietary ingredients are presented in Tables 1 and 2, respectively. Daily DMI $(20 \pm 0.5 \mathrm{~kg} / \mathrm{d}$; Fanchone et al., 2013) and duodenal flow of DM $(12.4 \pm 0.72 \mathrm{~kg} / \mathrm{d})$ were not affected by treatments $(P \geq 0.36$ for $\mathrm{N}$ level, carbohydrate source and their interaction). Therefore, differences in daily intake of $\mathrm{B}$ vitamins depended mostly on 
Table 2. B-vitamin concentrations $(\mathrm{mg} / \mathrm{kg}$ of $\mathrm{DM} \pm \mathrm{SD} ; \mathrm{n}=4)$ in the dietary ingredients fed to the dairy cows

\begin{tabular}{|c|c|c|c|c|c|c|c|c|}
\hline Item & Corn silage & Hay & $\begin{array}{l}\text { Dehydrated } \\
\text { alfalfa }\end{array}$ & $\begin{array}{c}\text { Molasses wheat } \\
\text { straw }\end{array}$ & $\begin{array}{l}\text { Cereal-based } \\
\text { concentrate }^{1}\end{array}$ & Soybean hulls & $\begin{array}{l}\text { Dehydrated } \\
\text { beet pulp }\end{array}$ & Soybean meal \\
\hline Thiamin & $1.37 \pm 0.03$ & $1.49 \pm 0.08$ & $2.92 \pm 0.09$ & $1.45 \pm 0.32$ & $4.92 \pm 0.24$ & $1.73 \pm 0.12$ & $0.95 \pm 0.03$ & $1.96 \pm 0.30$ \\
\hline Riboflavin & $73.2 \pm 4.05$ & $35.0 \pm 2.96$ & $100.4 \pm 11.12$ & $96.9 \pm 20.08$ & $30.6 \pm 3.16$ & $23.6 \pm 4.12$ & $20.2 \pm 1.53$ & $34.4 \pm 6.81$ \\
\hline Vitamin $B_{6}$ & $15.0 \pm 1.88$ & $4.2 \pm 0.01$ & $8.1 \pm 0.59$ & $15.9 \pm 2.64$ & $6.1 \pm 0.07$ & $1.6 \pm 0.54$ & $1.6 \pm 0.23$ & $3.8 \pm 0.50$ \\
\hline Folates & $0.10 \pm 0.02$ & $0.38 \pm 0.06$ & $2.81 \pm 0.16$ & $0.21 \pm 0.03$ & $0.23 \pm 0.02$ & $1.13 \pm 0.08$ & $0.05 \pm 0.01$ & $1.96 \pm 0.75$ \\
\hline Vitamin $B_{12}$ & $0.005 \pm 0.002$ & $0.011 \pm 0.005$ & $0.006 \pm 0.002$ & $0.003 \pm 0.002$ & $0.001 \pm 0.001$ & $0.001 \pm 0.001$ & $0.001 \pm 0.001$ & $0.001 \pm 0.001$ \\
\hline
\end{tabular}

${ }^{1}$ Cereal-based concentrate: $39 \%$ barley, $46 \%$ wheat, and $15 \%$ corn on a DM basis.

the vitamin concentrations of the ingredients and their relative proportions in the experimental diets, whereas differences in B-vitamin duodenal flow were mostly due to B-vitamin concentrations in digesta. Average vitamin intake, duodenal flow, and ARS are presented in Table 3.

\section{Thiamin}

Thiamin daily intake, duodenal flow, and ARS were not affected $(P \geq 0.28)$ by the $\mathrm{N}$ level. Thiamin intake was greater with the high-starch diets $(P<0.01 ; 51.1$ vs. $34.2 \pm 2.36 \mathrm{mg} / \mathrm{d}$; Table 3 ) as a consequence of the higher concentrations of thiamin in diets rich in starch $(2.54 \mathrm{mg} / \mathrm{kg}$ of DM; Table 1) as compared with high-fiber diets $(1.60 \mathrm{mg} / \mathrm{kg}$ of DM; Table 1$)$. Nevertheless, thiamin duodenal flow or ARS did not differ statistically $(P \geq 0.41)$ between carbohydrate sources. This is in accordance with the study of Schwab et al.
(2006), who found no effect of different dietary forage and nonfiber carbohydrate contents on thiamin ARS. Thiamin ARS was positively correlated only with total VFA, as previously observed by Schwab et al. (2006).

\section{Riboflavin}

Riboflavin intake did not differ $(P=0.90)$ between dietary $\mathrm{N}$ levels, but the high-N diets increased duodenal flow $(P=0.03 ; 1,156$ vs. $1,481 \pm 85.5 \mathrm{mg} / \mathrm{d})$ and ARS $(P=0.04 ; 43$ vs. $372 \pm 95.2 \mathrm{mg} / \mathrm{d})$ of riboflavin. These results are in accordance with the study of Lardinois et al. (1944), who reported that the apparent synthesis of riboflavin was greater when the diet contained more degradable $\mathrm{N}$ (7.6 vs. $13.6 \mu \mathrm{g}$ of riboflavin/g of DM of rumen content). Feeding diets rich in starch resulted in greater intake and duodenal flow of riboflavin $(P=0.01 ; 1,172$ vs. $1,050 \pm 25.8 \mathrm{mg} / \mathrm{d}$ and $P$ $=0.01 ; 1,545$ vs. $1,091 \pm 92.4 \mathrm{mg} / \mathrm{d}$, respectively) and

Table 3. Intake, duodenal flow, and apparent ruminal synthesis (ARS) of thiamin, riboflavin, niacin, vitamin $\mathrm{B}_{6}$, folates, and vitamin $\mathrm{B}_{12}$ of cows receiving high-starch or high-fiber concentrate at a low or high $\mathrm{N}$ level

\begin{tabular}{|c|c|c|c|c|c|c|c|c|}
\hline \multirow[b]{2}{*}{ Item } & \multicolumn{2}{|c|}{ Low N } & \multicolumn{2}{|c|}{ High N } & \multirow[b]{2}{*}{ SEM } & \multicolumn{3}{|c|}{$P$-value } \\
\hline & Starch & Fiber & Starch & Fiber & & $\mathrm{N}$ & $\mathrm{C}^{1}$ & $\mathrm{~N} \times \mathrm{C}$ \\
\hline \multicolumn{9}{|l|}{ Intake, mg/d } \\
\hline Thiamin & 52.6 & 31.7 & 49.5 & 36.7 & 3.34 & 0.76 & $<0.01$ & 0.27 \\
\hline Riboflavin & 1,193 & 1,033 & 1,151 & 1,067 & 36.5 & 0.90 & 0.01 & 0.35 \\
\hline Niacin & 2,143 & 2,170 & 2,135 & 2,215 & 70.9 & 0.78 & 0.50 & 0.73 \\
\hline Vitamin $\mathrm{B}_{6}$ & 206 & 158 & 198 & 164 & 5.6 & 0.87 & $<0.01$ & 0.23 \\
\hline Folates & 9.9 & 14.0 & 11.6 & 15.9 & 0.52 & 0.01 & $<0.01$ & 0.86 \\
\hline Vitamin $B_{12}$ & 0.10 & 0.10 & 0.10 & 0.08 & 0.003 & 0.43 & 0.56 & 0.84 \\
\hline \multicolumn{9}{|c|}{ Duodenal flow, mg/d } \\
\hline Thiamin & 36.1 & 24.7 & 45.4 & 37.5 & 10.29 & 0.28 & 0.41 & 0.88 \\
\hline Riboflavin & 1,362 & 949 & 1,729 & 1,233 & 130.6 & 0.03 & 0.01 & 0.78 \\
\hline Niacin & 1,473 & 1,166 & 1,604 & 1,530 & 147.8 & 0.10 & 0.26 & 0.48 \\
\hline Vitamin $\mathrm{B}_{6}$ & 53.0 & 41.6 & 84.4 & 49.7 & 6.98 & 0.01 & 0.01 & 0.15 \\
\hline Folates & 27.2 & 23.4 & 45.1 & 35.1 & 5.22 & 0.01 & 0.25 & 0.59 \\
\hline Vitamin $B_{12}$ & 2.78 & 9.19 & 3.47 & 9.44 & 1.034 & 0.64 & $<0.01$ & 0.85 \\
\hline \multicolumn{9}{|l|}{$\mathrm{ARS}, \mathrm{mg} / \mathrm{d}$} \\
\hline Thiamin & -16.5 & -7.0 & -4.1 & 0.8 & 11.19 & 0.36 & 0.56 & 0.85 \\
\hline Riboflavin & 169 & -84 & 578 & 166 & 145.4 & 0.04 & 0.06 & 0.62 \\
\hline Niacin & -670 & $-1,003$ & -530 & -684 & 138.7 & 0.11 & 0.14 & 0.56 \\
\hline Vitamin $\mathrm{B}_{6}$ & -153 & -116 & -113 & -115 & 9.6 & 0.04 & 0.11 & 0.09 \\
\hline Folates & 17.3 & 9.4 & 33.5 & 19.2 & 5.14 & 0.02 & 0.07 & 0.58 \\
\hline Vitamin $\mathrm{B}_{12}$ & 2.70 & 9.12 & 3.38 & 9.36 & 1.033 & 0.65 & $<0.01$ & 0.85 \\
\hline
\end{tabular}


tended to increase ARS $(P=0.06 ; 373$ vs. $41 \pm 102.8$ $\mathrm{mg} / \mathrm{d})$. This trend to increase ARS is in line with the study of Santschi et al. (2005b), in which a low-forage diet led to a greater riboflavin concentration in the solid-associated bacteria fraction than a high-forage diet. Hunt et al. (1943) showed that rumen riboflavin concentration increased when a rapidly fermentable carbohydrate source was added to the diet. In the present study, the diets were isoenergetic, but it can be hypothesized that the bacterial population responsible for starch degradation produces more riboflavin than the bacterial population involved in fiber degradation. This hypothesis is supported by the negative correlation between riboflavin ARS and NDF and ADF intakes, as well as with NDF ruminally digested $(\mathrm{kg} / \mathrm{d}$; Table 4). As recently performed for the human gut microbiota (Magnúsdóttir et al., 2015), a genome assessment of the B-vitamin biosynthetic pathway among rumen microbes would help to validate this hypothesis and to understand the effect of the microbiota composition (in line with the diet composition) on B-vitamin synthesis. Riboflavin ARS was strongly negatively correlated with ruminal protein balance and had a high positive correlation with microbial synthesis efficiency, whether in the liquid-associated bacteria fraction or in the mixed bacteria fraction, which contained both solid- and liquid-associated bacteria. Lastly, ARS was positively correlated with NAN duodenal flows (Table 4). All these results would suggest, notwithstanding possible changes in ruminal bacteria species, that riboflavin synthesis in rumen was greater under dietary conditions promoting microbial growth (i.e., readily available sources of degradable carbohydrates and N).

\section{Niacin}

Daily intake of niacin was not affected by dietary treatments $(P \geq 0.50)$. However, high- $\mathrm{N}$ diets tended

Table 4. Pearson correlation coefficients between B-vitamin apparent ruminal synthesis (ARS, mg/d) and dietary and digestive parameters

\begin{tabular}{|c|c|c|c|c|c|c|}
\hline \multirow[b]{2}{*}{ Item } & \multicolumn{6}{|c|}{ B-vitamin ARS } \\
\hline & Thiamin & Riboflavin & Niacin & Vitamin $\mathrm{B}_{6}$ & Folates & Vitamin $\mathrm{B}_{12}$ \\
\hline \multicolumn{7}{|l|}{ Intake, $\mathrm{kg} / \mathrm{d}$} \\
\hline $\mathrm{DM}$ & -0.31 & -0.42 & -0.15 & -0.27 & -0.40 & 0.29 \\
\hline $\mathrm{OM}$ & -0.44 & -0.45 & -0.18 & -0.33 & -0.38 & 0.22 \\
\hline NDF & 0.09 & $-0.70^{* *}$ & $-0.56^{*}$ & 0.15 & $-0.66^{* *}$ & $0.85^{* * *}$ \\
\hline $\mathrm{ADF}$ & 0.11 & $-0.70^{* *}$ & $-0.58^{*}$ & 0.17 & $-0.67^{* *}$ & $0.85^{* * *}$ \\
\hline Starch & -0.31 & 0.49 & 0.47 & -0.39 & 0.45 & $-0.85^{* * *}$ \\
\hline $\mathrm{N}$ & 0.15 & 0.23 & 0.28 & 0.31 & 0.31 & 0.22 \\
\hline Intake of vitamins, ${ }^{1} \mathrm{mg} / \mathrm{d}$ & -0.40 & -0.15 & -0.27 & $-0.64^{* *}$ & -0.36 & -0.28 \\
\hline \multicolumn{7}{|l|}{ Ruminally digested, $\mathrm{kg} / \mathrm{d}$} \\
\hline NDF & 0.04 & $-0.61^{*}$ & -0.49 & 0.18 & -0.49 & $0.77^{* * *}$ \\
\hline Starch & -0.34 & 0.47 & 0.46 & -0.43 & 0.47 & $-0.88^{* * *}$ \\
\hline \multicolumn{7}{|l|}{ Ruminal measures } \\
\hline Ruminal protein balance, ${ }^{2} \mathrm{~g}$ of $\mathrm{CP} / \mathrm{kg}$ of $\mathrm{DMI}$ & -0.20 & $-0.70^{* *}$ & $-0.66^{* *}$ & -0.09 & -0.39 & 0.29 \\
\hline \multicolumn{7}{|l|}{ VFA } \\
\hline Total, $\mathrm{m} M$ & $0.65^{* *}$ & 0.17 & 0.45 & 0.31 & -0.14 & $0.54^{*}$ \\
\hline Acetate, $\%$ total VFA & 0.40 & 0.16 & 0.05 & 0.19 & -0.01 & 0.46 \\
\hline Propionate, \% total VFA & -0.17 & -0.46 & -0.42 & -0.19 & -0.25 & 0.08 \\
\hline Butyrate, $\%$ total VFA & -0.37 & -0.02 & 0.14 & -0.22 & 0.03 & $-0.50^{*}$ \\
\hline $\mathrm{pH}$ & 0.07 & -0.11 & -0.38 & 0.19 & -0.005 & 0.12 \\
\hline $\mathrm{NH}_{3}-\mathrm{N}$ & 0.32 & -0.10 & -0.10 & 0.45 & -0.01 & $0.60^{*}$ \\
\hline $\mathrm{LAB} M S E{ }^{3} \mathrm{~g}$ of $\mathrm{N} / \mathrm{kg}$ of OMTRD & 0.21 & $0.73^{* *}$ & $0.54^{*}$ & 0.33 & $0.61^{*}$ & -0.26 \\
\hline $\mathrm{MB} \mathrm{MSE},{ }^{4} \mathrm{~g}$ of $\mathrm{N} / \mathrm{kg}$ of OMTRD & 0.22 & $0.71^{* *}$ & $0.57^{*}$ & 0.36 & $0.57^{*}$ & -0.21 \\
\hline \multicolumn{7}{|l|}{ Isotrichidae $/ \mathrm{mL}$} \\
\hline Time postfeeding: $0 \mathrm{~h}$ & -0.23 & -0.12 & -0.02 & 0.26 & -0.00 & 0.19 \\
\hline Time postfeeding: $2.5 \mathrm{~h}$ & 0.10 & -0.34 & -0.31 & 0.19 & -0.33 & 0.43 \\
\hline \multicolumn{7}{|l|}{ Ophryoscolecidae/mL } \\
\hline Time postfeeding: $0 \mathrm{~h}$ & 0.18 & 0.05 & 0.33 & 0.34 & -0.11 & 0.27 \\
\hline Time postfeeding: $2.5 \mathrm{~h}$ & 0.35 & 0.23 & 0.35 & 0.35 & 0.10 & 0.34 \\
\hline \multicolumn{7}{|l|}{ Duodenal measures } \\
\hline NAN duodenal flow, g/d & 0.25 & $0.67^{* *}$ & $0.68^{* *}$ & 0.29 & $0.51^{* *}$ & -0.05 \\
\hline
\end{tabular}

${ }^{1}$ Intake of the corresponding $\mathrm{B}$ vitamin.

${ }^{2}$ Ruminal protein balance $=(\mathrm{N}$ intake - duodenal NAN flow $) \times 6.25 / \mathrm{DMI}$.

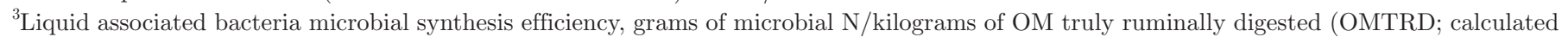
using LAB as microbial reference sample).

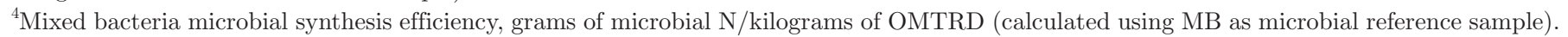

${ }^{*} P<0.05,{ }^{*} * P<0.01,{ }^{*} * * P<0.001$. 
to increase niacin duodenal flow $(P=0.10 ; 1,320$ vs. $1,567 \pm 96.8 \mathrm{mg} / \mathrm{d})$, possibly due to a numerically decreased degradation of the vitamin in the rumen $(P$ $=0.11 ;-837$ vs. $-608 \pm 90.8 \mathrm{mg} / \mathrm{d})$, regardless of carbohydrate source $(P \geq 0.14$; Table 3$)$. In the present trial, niacin was degraded in the rumen (negative values for ARS) in all dietary treatments, contrary to other previous experiments where niacin ARS was positive (Miller et al., 1986; Santschi et al., 2005a; Schwab et al., 2006). However, niacin intake in this trial was up to 4 fold higher than those studies, which could explain the ruminal synthesis differences. Santschi et al. (2005a) also observed that increasing niacin intake by using a supplement had no effect on niacin duodenal flow because the supplementary niacin was almost completely destroyed in rumen. As with riboflavin, niacin ARS was negatively correlated with ADF and NDF intake. We found a strong negative correlation between ARS and ruminal protein balance and a positive correlation between ARS and microbial synthesis efficiency (LAB and MB) and with NAN duodenal flows (Table 4). These observations suggest that apparent degradation of niacin in rumen was reduced under the same conditions that promoted riboflavin ARS.

\section{Vitamin $B_{6}$}

The dietary $\mathrm{N}$ level had no effect on intake of vitamin $\mathrm{B}_{6}(P=0.87$; Table 3$)$, but the low- $\mathrm{N}$ diets decreased its duodenal flow $(P=0.01 ; 47.3$ vs. $67.1 \pm 4.57 \mathrm{mg} / \mathrm{d})$. Vitamin $\mathrm{B}_{6}$ intake $(P<0.01 ; 202$ vs. $161 \pm 3.9 \mathrm{mg} / \mathrm{d})$ and duodenal flow $(P=0.01 ; 68.7$ vs. $45.7 \pm 4.94$ $\mathrm{mg} / \mathrm{d})$ were greater with the starch diets. The carbohydrate source had no effect on apparent degradation (negative ARS) of vitamin $\mathrm{B}_{6}$ in rumen of cows fed the high-N diets $(P=0.93)$, but starch increased the vitamin degradation in rumen of cows fed low-N diets $(P=0.03$; interaction $\mathrm{N}$ level $\times$ carbohydrate source, $P$ $=0.09$; Table 3). Santschi et al. (2005a) also observed apparent ruminal degradation of vitamin $\mathrm{B}_{6}$ in rumen, whereas Schwab et al. (2006) observed positive ARS. It is worthy of note that vitamin $\mathrm{B}_{6}$ intake was 2.4 times greater in the study of Santschi et al. (2005a) than in Schwab et al. (2006). In the present study, vitamin $\mathrm{B}_{6}$ ARS was negatively correlated with the intake of the vitamin, suggesting a possible downregulation of its synthesis by its availability (Table 4). This result is similar to what was observed by Castagnino et al. (2015).

\section{Folates}

Regardless of the diet composition, folate ARS was positive and values obtained in the current experiment were in the same range as the ones reported in earlier studies (Santschi et al., 2005a; Schwab et al., 2006). The low- $\mathrm{N}$ diets decreased intake, duodenal flow, and ARS of folates $(P=0.01 ; 12.0$ vs. $13.7 \pm 0.34 \mathrm{mg} / \mathrm{d} ; P$ $=0.01 ; 25.3$ vs. $40.1 \pm 3.41 \mathrm{mg} / \mathrm{d}$; and $P=0.02 ; 13.3$ vs. $26.4 \pm 3.37 \mathrm{mg} / \mathrm{d}$, respectively), although Lardinois et al. (1944) observed no direct correlation between increased urea intake and folate concentration in rumen content. The high-starch diets resulted in lower intakes of folates $(P<0.01 ; 10.7$ vs $15.0 \pm 0.37 \mathrm{md} / \mathrm{d})$, had no effects on duodenal flow $(P=0.25)$, but tended to increase ARS $(P=0.07 ; 14.3$ vs. $25.4 \pm 3.64 \mathrm{mg} / \mathrm{d})$. Increasing concentration of nonfiber carbohydrates has been reported to increase folate duodenal flow and ARS, whereas increasing forage proportion in the diet had opposite effects (Schwab et al., 2006).

Correlations between folate ARS and dietary parameters follow the same trends as riboflavin and niacin ARS. Folate ARS was strongly negatively correlated with $\mathrm{ADF}$ and NDF intakes and positively correlated with the microbial synthesis efficiency (LAB and MB) as well as with NAN duodenal flows (Table 4).

\section{Vitamin $B_{12}$}

The intake of vitamin $B_{12}$ was not affected by the $\mathrm{N}$ level or the carbohydrate source of the diet. In fact, intake of the vitamin was negligible (Tables 2 and 3) because vitamin $\mathrm{B}_{12}$ is synthesized only by bacteria and, except for contamination, is therefore absent in feeds from plant origin (Combs, 2012). Consequently, as the supply via feed is very limited, values for duodenal flow and ARS were similar. The dietary level of $\mathrm{N}$ had no effects on vitamin $\mathrm{B}_{12}$ ARS ( $P=0.65$; Table 3$)$. Unlike all other $\mathrm{B}$ vitamins studied, fiber-rich diets enhanced ARS of vitamin $\mathrm{B}_{12}(P<0.01 ; 9.23$ vs. $3.04 \pm 0.730$ $\mathrm{mg} / \mathrm{d}$, respectively). In accordance with Schwab et al. (2006), vitamin $B_{12}$ ARS had a strong positive correlation with $\mathrm{ADF}$ and NDF intakes, whereas a negative correlation was observed with starch intake. Similarly, the synthesis of vitamin $B_{12}$ was correlated positively and negatively with NDF and starch ruminally digested, respectively. Vitamin $\mathrm{B}_{12}$ synthesis was positively correlated with total VFA, acetate, and ammonia-N, but negatively correlated with butyrate. Dryden and Hartman (1971) also observed a negative correlation between butyrate and vitamin $\mathrm{B}_{12}$ concentration.

Cobalt is essential to produce vitamin $\mathrm{B}_{12}$ (McDowell, 2000). In the present study, supplemental Co was similar among treatments $(7.2 \mathrm{mg} / \mathrm{d})$, but total Co intake was affected by the $\mathrm{N}$ level $(P<0.01 ; 21.1$ vs. $17.6 \pm 0.41 \mathrm{mg} / \mathrm{d}$ for high and low $\mathrm{N}$ levels, respectively) and the carbohydrate source $(P<0.01 ; 22.2$ vs. $16.5 \pm 0.44 \mathrm{mg} / \mathrm{d}$ for high-fiber and high-starch diets, 
respectively). Therefore, we can hypothesize that the higher Co concentration in the fiber-rich diets induced a greater vitamin $B_{12}$ synthesis. These results are in accordance with the ones reported by Sutton and Elliot (1972), in which Co intake decreased as the concentrate content of the diet increased. They also observed a significantly lower vitamin $\mathrm{B}_{12}$ synthesis with a forageto-concentrate ratio of 40:60 compared with ratios of 70:30 and 100:0. Furthermore, in the current study, we observed a highly positive correlation between total Co intake and vitamin $\mathrm{B}_{12}$ ARS $(P<0.01 ; \mathrm{r}=0.79)$. Vitamin $\mathrm{B}_{12}$ ARS in the present experiment was much lower than the values observed by Schwab et al. (2006; $60.1-102.2 \mathrm{mg} / \mathrm{d}$ ) or Santschi et al. (2005a; $73 \mathrm{mg} / \mathrm{d}$ ) with diets with a higher total Co concentration than in the present study. Hedrich et al. (1973) also observed, in sheep, that increasing Co intakes resulted in a higher vitamin $\mathrm{B}_{12}$ production. Consequently, it is difficult to dissociate the effects of Co supply itself on vitamin $\mathrm{B}_{12}$ production in the rumen from those due to dietary carbohydrate source.

\section{CONCLUSIONS}

Overall, in the present study there was an apparent synthesis of riboflavin, folates, and vitamin $\mathrm{B}_{12}$ but an apparent degradation of thiamin, niacin, and vitamin $\mathrm{B}_{6}$ in rumen. The high-starch diets increased ARS of riboflavin and folates and reduced apparent ruminal degradation of vitamin $\mathrm{B}_{6}$, whereas vitamin $\mathrm{B}_{12} \mathrm{ARS}$ was greater with the high-fiber diets. The low-N diets decreased ARS of riboflavin and folates. Overall, riboflavin, niacin, and folate apparent synthesis in rumen was negatively correlated with NDF and ADF intakes, whereas vitamin $\mathrm{B}_{12}$ followed the opposite pattern. In the range of the studied diets, which all had the same forage-to-concentrate ratio, thiamin and vitamin $\mathrm{B}_{6}$ were not influenced by the intake of nutrients. Moreover, only vitamin $\mathrm{B}_{6} \mathrm{ARS}$ was correlated with its intake. The current study confirmed that characteristics of the diet influence B-vitamin supply for dairy cows, probably by affecting microbial population and activity.

\section{ACKNOWLEDGMENTS}

The authors thank Chrystiane Plante (Agriculture and Agri-Food Canada, Sherbrooke, QC, Canada) for her technical support, during the last 2 decades she developed and validated the methods for B-vitamin analyses described in the present paper. Analysis of B-vitamin concentrations in feed and digesta samples collected during a study financially supported by the Commission of the European Communities, project FP7-KBBE-2007-1 "Rednex," was funded by the Pro- gramme de recherche en partenariat pour l'innovation en production et transformation laitière NovalaitAgriculture et Agroalimentaire Canada-Fonds de recherché du Québec Nature et Technologies-Ministère de l'Agriculture, des Pêcheries et de l'Alimentation du Québec (Québec, Canada).

\section{REFERENCES}

AOAC International. 2005. Official Methods of Analysis. 18th ed. AOAC International, Gaithersburg, MD.

Bach, A., S. Calsamiglia, and M. D. Stern. 2005. Nitrogen metabolism in the rumen. J. Dairy Sci. 88:E9-E21. http://dx.doi.org/10.3168/ jds.S0022-0302(05)73133-7.

Bechdel, S. I., and H. E. Honeywell. 1927. The relation between the vitamin B content of the feed eaten and of the milk produced. J. Agric. Res. 35:283-288.

Bechdel, S. I., H. E. Honeywell, R. A. Dutcher, and M. H. Knutsen. 1928. Synthesis of vitamin B in the rumen of the cow. J. Biol. Chem. 80:231-238.

Belanche, A., M. Doreau, J. E. Edwards, J. M. Moorby, E. Pinloche, and C. J. Newbold. 2012. Shifts in the rumen microbiota due to the type of carbohydrate and level of protein ingested by dairy cattle are associated with changes in rumen fermentation. J. Nutr. 142:1684-1692. http://dx.doi.org/10.3945/jn.112.159574.

Bellanger, J. 1988. Détermination du cobalt-EDTA dans les contenus duodénaux. Reprod. Nutr. Dev. 28:103-104.

Bird, O. D., and V. M. McGlohon. 1972. Differential assays of folic acid in animal tissues. Pages 409-437 in Analytical Microbiology. Vol. 2. F. Kavanagh, ed. Academic Press, New York, NY.

Bötticher, B., and D. Bötticher. 1986. Simple rapid determination of thiamin by a HPLC method in foods, body fluids, urine and faeces. Int. J. Vitam. Nutr. Res. 56:155-159.

Castagnino, D., K. L. Kammes, J. A. Voelker Linton, M. S. Allen, M. Seck, R. Gervais, P. Y. Chouinard, and C. L. Girard. 2015. Apparent synthesis of vitamin B6 and folates in rumen of lactating dairy cows fed alfalfa or orchardgrass silages. J. Dairy Sci. 98(ESuppl.): 457

CCAC (Canadian Council on Animal Care). 1993. Guide to the Care and Use of Experimental Animals. CCAC, Ottawa, ON, Canada.

Combs, G. F. 2012. The Vitamins. 4th ed. Elsevier Inc., San Diego, CA.

Dryden, L. P., and A. M. Hartman. 1971. Variations in the amount and relative distribution of vitamin and its analogs in the bovine rumen. J. Dairy Sci. 54:235-246. http://dx.doi.org/10.3168/jds. S0022-0302(71)85818-6.

Fanchone, A., P. Nozière, J. Portelli, B. Duriot, V. Largeau, and M. Doreau. 2013. Effects of nitrogen underfeeding and energy source on nitrogen ruminal metabolism, digestion, and nitrogen partitioning in dairy cows. J. Anim. Sci. 91:895-906. http://dx.doi. org/10.2527/jas.2012-5296.

Giguère, A., C. L. Girard, and J. J. Matte. 2002. Erythrocyte glutathione reductase activity and riboflavin nutritional status in early-weaned piglets. Int. J. Vitam. Nutr. Res. 72:383-387. http:// dx.doi.org/10.1024/0300-9831.72.6.383.

Girard, C. L., and J. J. Matte. 1998. Dietary supplements of folic acid during lactation: Effects on the performance of dairy cows. J. Dairy Sci. 81:1412-1419. http://dx.doi.org/10.3168/jds.S00220302(98)75705-4.

Graulet, B., J. J. Matte, A. Desrochers, L. Doepel, M. F. Palin, and C. L. Girard. 2007. Effects of dietary supplements of folic acid and vitamin $\mathrm{B}_{12}$ on metabolism of dairy cows in early lactation. J. Dairy Sci. 90:3442-3455. http://dx.doi.org/10.3168/jds.2006-718.

Hedrich, M. F., J. M. Elliot, and J. E. Lowe. 1973. Response in vitamin $\mathrm{B}_{12}$ production and absorption to increasing cobalt intake in the sheep. J. Nutr. 103:1646-1651.

Hristov, A. N., M. Ivan, L. M. Rode, and T. A. McAllister. 2001 Fermentation characteristics and ruminal ciliate protozoal popula- 
tions in cattle fed medium- or high-concentrate barley-based diets. J. Anim. Sci. 79:515-524.

Hunt, C. H., E. W. Burroughs, R. M. Bethke, A. F. Schalk, and P. Gerlaugh. 1943. Further studies on riboflavin and thiamin in the rumen content of cattle. II. J. Nutr. 25:207-216.

Hyun, T. H., and T. Tamura. 2005. Trienzyme extraction in combination with microbiologic assay in food folate analysis: An updated review. Exp. Biol. Med. (Maywood) 230:444-454.

INRA. 2007. Alimentation des Bovins, Ovins et Caprins. Besoins des animaux - Valeurs des Aliments. Quae Editions, Paris, France.

Jakobsen, J. 2008. Optimisation of the determination of thiamin, 2-(1-hydroxyethyl)thiamin, and riboflavin in food samples by use of HPLC. Food Chem. 106:1209-1217. http://dx.doi.org/10.1016/j. foodchem.2007.06.008.

Jaster, E. H., and N. E. Ward. 1990. Supplemental nicotinic acid or nicotinamide for lactating dairy cows. J. Dairy Sci. 73:2880-2887. http://dx.doi.org/10.3168/jds.S0022-0302(90)78975-8.

Johnson, K. A., and D. E. Johnson. 1995. Methane emissions from cattle. J. Anim. Sci. 73:2483-2492.

Kon, S. K., and J. W. G. Porter. 1954. The intestinal synthesis of vitamins in the ruminant. Vitam. Horm. 12:53-68.

Lahély, S., M. Bergaentzlé, and C. Hasselmann. 1999. Fluorimetric determination of niacin in foods by high-performance liquid chromatography with post-column derivatization. Food Chem. 65:129133. http://dx.doi.org/10.1016/S0308-8146(98)00182-4.

Lardinois, C. C., R. C. Mills, C. A. Elvehjem, and E. B. Hart. 1944. Rumen synthesis of the vitamin B complex as influenced by ration composition. J. Dairy Sci. 27:579-583. http://dx.doi.org/10.3168/ jds.S0022-0302(44)92635-4.

Magnúsdóttir, S., D. Ravcheev, V. de Crécy-Lagard, and I. Thiele. 2015. Systematic assessment of B-vitamin biosynthesis suggests co-operation among gut microbes. Front. Genet. 6:148. http:// dx.doi.org/10.3389/fgene.2015.00148.

Matte, J. J., A. A. Ponter, and B. Sève. 1997. Effects of chronic parental pyridoxine and acute enteric tryptophan on pyridoxine status, glycemia and insulinemia stimulated by enteric glucose in weanling piglets. Can. J. Anim. Sci. 77:663-668. http://dx.doi.org/10.4141/ A97-013.

Mawatari, K., F. Iinuma, and M. Watanabe. 1991. Determination of nicotinic acid and nicotinamide in human serum by high-performance liquid-chromatography with postcolumn ultraviolet-irradiation and fluorescence detection. Anal. Sci. 7:733-736. http:// dx.doi.org/10.2116/analsci.7.733.

McDowell, L. R. 2000. Vitamins in Animal and Human Nutrition. 2nd ed. Wiley, Ames, IA.

Miller, B. L., J. C. Meiske, and R. D. Goodrich. 1986. Effects of grain source and concentrate level on B-vitamin production and absorption in steers. J. Anim. Sci. 62:473-483.
Ministère de l'Alimentation, de l'Agriculture et de la Pêche. 2009. Arrêté no. AGRG0927736A du 30 novembre 2009 modifiant l'arrêté du 19 avril 1988 fixant les conditions d'attribution de l'autorisation de pratiquer des expériences sur les animaux. J. Off. Répub. Fr. 1 Dec. Accessed June 21, 2014. http://afstal.com/medias/File/ arrete-30-novembre-2009.pdf.

Ndaw, S., M. Bergaentzle, D. Aoude-Werner, and C. Hasselmann. 2002. Enzymatic extraction procedure for the liquid chromatographic determination of niacin in foodstuffs. Food Chem. 78:129-134. http://dx.doi.org/http://dx.doi.org/10.1016/S03088146(02)00205-4.

NRC. 2001. Nutrient Requirements of Dairy Cattle. 7th ed. Natl. Acad. Press, Washington, DC.

Santschi, D. E., R. Berthiaume, J. J. Matte, A. F. Mustafa, and C. L. Girard. 2005a. Fate of supplementary B-vitamins in the gastrointestinal tract of dairy cows. J. Dairy Sci. 88:2043-2054. http:// dx.doi.org/10.3168/jds.S0022-0302(05)72881-2 .

Santschi, D. E., J. Chiquette, R. Berthiaume, R. Martineau, J. J. Matte, A. F. Mustafa, and C. L. Girard. 2005b. Effects of the forage to concentrate ratio on B-vitamin concentrations in different ruminal fractions of dairy cows. Can. J. Anim. Sci. 85:389-399. http://dx.doi.org/10.4141/A05-012.

SAS. 2008. SAS User's Guide: Statistics. Version 9.2 ed. SAS Institute Inc., Cary, NC.

Schwab, E. C., C. G. Schwab, R. D. Shaver, C. L. Girard, D. E. Putnam, and N. L. Whitehouse. 2006. Dietary forage and nonfiber carbohydrate contents influence B-vitamin intake, duodenal flow, and apparent ruminal synthesis in lactating dairy cows. J. Dairy Sci. 89:174-187. http://dx.doi.org/10.3168/jds.S00220302(06)72082-3.

Shaver, R. D., and M. A. Bal. 2000. Effect of dietary thiamin supplementation on milk production by dairy cows. J. Dairy Sci. 83:23352340. http://dx.doi.org/10.3168/jds.S0022-0302(00)75121-6.

Srivastava, S. K., and E. Beutler. 1973. A new fluorometric method for the determination of pyridoxal 5'-phosphate. Biochim. Biophys. Acta 304:765-773. http://dx.doi.org/10.1016/0304-4165(73)902237 .

Sutton, A. L., and J. M. Elliot. 1972. Effect of ratio of roughage to concentrate and level of feed intake on ovine ruminal vitamin $B_{12}$ production. J. Nutr. 102:1341-1346.

Tamura, T., Y. S. Shin, M. A. Williams, and E. L. R. Stokstad. 1972. Lactobacillus casei response to pteroylpolyglutamates. Anal. Biochem. 49:517-521. http://dx.doi.org/10.1016/00032697(72)90456-3. 